Trivent Publishing

(C) The Authors, 2015

Available online at http://trivent-publishing.eu/

Philosophy, Communication, Media sciences Series

Volume Saint Gerard of Cenad: Tradition and Innovation

\title{
Bishop Augustin Pacha (1870-1954) The Years of Imprisonment and His Release Shortly before His Death
}

\author{
Claudiu Călin \\ Roman-Catholic Diocese of Timişoara \\ (Archivum Dioecesanum Timisoarense / Archives of the Diocese of Timişoara), Romania, \\ duratti2002@yahoo.de
}

\begin{abstract}
Augustin Pacha, Bishop of the Diocese of Timisoara, shepherded the Catholics of Banat for over three decades. He lived through the dualist monarchy, the First World War, as well as through the social changes of the interwar period. An enemy to nationalism and socialism, and a supporter of the German Christian Catholic identity of the Swabians in Banat, Pacha was a member of the intellectual elite persecuted and even eliminated by the communists after 1948. Arrested in 1950 and sentenced to prison in 1951 in a show trial, the old bishop was released in the summer of 1954. The communist regime knew he was dying. This decision is interesting in the context of the time and even today, 60 years later.
\end{abstract}

Keywords: bishop; diocese; Augustin Pacha; imprisonment; trial; Catholic Church; communists; swabians

This is an Open Access article distributed in accordance with the Creative Commons Attribution Non Commercial (CC-BYNC-ND 4.0) license, which permits others to copy or share the article, provided original work is properly cited and that this is not done for commercial purposes. Users may not remix, transform, or build upon the material and may not distribute the modified material (http://creativecommons.org/licenses/by-nc/4.0/)

DOI: $10.22618 /$ TP.PCMS.20151.176009 


\section{Călin \\ Bishop Augustin Pacha (1870-1954)The Years of Imprisonment and His \\ Release Shortly before His Death \\ I. Instead of an Introduction: Secret internal debates of the Political Bureau of the Romanian Workers Party about the liberation of an old Catholic bishop}

The trials and tribulations underlying the release of Augustin Pacha (1870-1954), Doctor Honoris Causa of the University or Münster in Germany, from the communist prison where he was thrown in the summer of 1950, and the following sentence to prison in $1954,{ }^{1}$ represented a genuine enigma for many people for a long time. Before public access to the archives of the former Securitate and the creation of CNSAS (National Council for the Study of the Securitate Archives), those who made all sorts of suppositions were not few and far between. The Securitate (Secret Police) seems to have done field research about the bishop and the people's reactions to a possible amnesty. Honorary canon Georg Wetzl, who was simultaneously a curate in the district of Timișoara IV Iosefin (German: Josefstadt), said that already before Pacha was released, he had been asked questions about the octogenarian bishop. Wetzl said that Pacha had always been a reconciliatory man, who did not aim to become a martyr. The bishop's situation was as such because of an intransigent American papal nuncio, who had once been sent to the Nunciature in Bucharest. Wetzl also added that in the spring of 1954 there was already talk around the city that Bishop Pacha would be released.

A very significant document that sheds some light on the matter of Bishop Augustin Pacha's release, as well as on the release of his younger brother in Christ, Márton Áron, was published in 2006 in Pro Memoria, a journal of ecclesiastic history, run by the Roman Catholic Archdiocese of Bucharest. It is actually an excerpt from the stenograph of the meeting of the Political Bureau of the Central Committee of the Romanian Workers Party on May 25 ${ }^{\text {th }}, 1954$. The participants counted Gheorghe Gheorghiu-Dej, Emil Bodnăraş, Alexandru Drăghici, Iosif Chişinevschi and Alexandru Moghioroş, who also made their contributions to the discussion. The unanimous opinion was that, after the death of Archbishop Alexandru Theodor Cisar of Bucharest, which took place in January $1954^{2}$ in mysterious circumstances even for the communists, the situation of the Romanian Roman Catholic Church was extremely delicate. The two archdioceses recognized by the communist regime the one in Alba Iulia and the one in Bucharest-Iaşi - had thus no leaders, and the members of the Political Bureau of the Central Committee of the Romanian Workers Party were afraid that the Holy See would soon take steps by appointing at least one successor. Such a step would not have been approved by the communists, as it would have proven once again that the Catholic Church in Romania was dependant on Rome. Upon analyzing the situation, the Bureau members concluded that there were already two bishops in Romania who could be considered as replacements: Augustin Pacha, who was 83 years old, retired with a state pension, and still a titular, in "Vatican documents" of an Episcopal see that was disbanded by the government, but who "according to catholic canons, still has the privilege to confer to another priest the grace to fulfil the position of a bishop;"3 and Márton Áron

\footnotetext{
1 *** Procesul unui grup de spioni, trădători şi complotişti în slujba Vaticanului şi a centrului de spionaj italian, București, 10-17 septembrie 1951 [The Trial of a group of spies, traitors and plotters in the service fo the Vatican and the Italian centre for espionage, Bucharest, 10-17 September 1951], published by The State Publishing House for Scientific Literature, Bucharest, 1952, was one of the numerous texts printed for propaganda by the communist party in Romania with the aim to compromise the Catholic Church in Romania and its clerics. This brochure deals with the trial of the "Pacha lot" from the point of view of the regime and following its own interests.

2 Dănuţ Doboş, “Arhidieceza de Bucureşti în perioada 1948-1989” [The Archdiocese of Bucharest during 19481989], in Biserica Romano-Catolică din România în timpul perioadei comuniste (1948-1989) [The Roman Catholic Church in Romania during the communist period (1948-1989)], edited by the National Commission for the Study of the History of the Roman Catholic Church in Romania, (Iaşi: Sapientia Publishing House, 2008$) 43$. ${ }^{3}$ Arhivele Militare Române (AMR - Romanian Militay Archives), Fond Microfilme (Microfilmes Found), rola (roll) AS1-409, c. 593-599 in Adrian Nicolae Petcu, Aspecte ale Represiunii Antireligioase în anii '50. Dosarul 15.563 [Aspects of the Antireligious Repression in the '50es], in Pro Memoria. Revisă de istorie Ecleziastică [Magazine for Ecclesiastical History], Nr. 5 / 2006, 232 (the article contains, as supplement, a note of the meeting of the Politic Bureau of the Central Comity of the Romanian Workers Party from the 25 $5^{\text {th }}$ of May 1954. The idea of using Pacha as a possible consecrator was expressed in that meeting by Emil Bodnăraș, the Minister of the Armed Forces (Defence), in that moment).
} 


\section{Călin 104 \\ Bishop Augustin Pacha (1870-1954)The Years of Imprisonment and His \\ Release Shortly before His Death}

(arrested on June $\left.21^{\text {st }}, 1949\right)^{4}$ of Alba Iulia. The discussions showed that the members of the Political Bureau wanted a solution to the issue of the Catholic Church, with the approval of the Holy See, and they tried, as a long-term step, to attract the good will of the people, as well as of the two abovementioned bishops. The communists were openly showing that they could not completely trust the attitude of the two bishops, but that they were generally regarded as temperate, intelligent people, one of whom was very old and even dying, but still "usable," while the other one was younger but deemed easy to work with.

In brief, it seems that - similar to the communists in neighbouring Hungary - there was a wish for the appointment and consecration of some bishops nominated by the state, with the approval of the Holy See that (according to the knowledge of the Political Bureau members) would have been willing to "accept two archdioceses within the country." $\mathrm{n}$ this respect, it was necessary for Pacha to be released and for Márton Áron to be brought to Bucharest for "treatment." Thus, from a canonical point of view, there was the possibility for existing bishops to be used for the consecration of one or several bishops approved by Rome and proposed by the communists. Moreover, Pacha was very old, ill and dying, and there was no need for him to be unnecessarily turned into a martyr. His wish was to die home, and, moreover: "He is no ordinary man; in my [i.e. Gheorghe Gheorghiu Dej] opinion, this will create, among the Catholic population, a new and favourable atmosphere for us." [my translation] Striking indeed is the resemblance between the description made by Emil Bodnăraş (which seems to have also been known by Gheorghe Gheorghiu-Dej) and the report of lieutenant colonel I. Saltuţiu on May $14^{\text {th }}, 1954^{7}$ : "He is disciplined, content with the way he is treated, has a respectful attitude; he is sorry to have ended up in prison; he wishes for freedom. By the way he talks, he wants to show that he is not hostile. In his condition, he is powerless." ${ }^{\prime 8}$ my translation]

Following the discussion thread and the details of the stenograph excerpt of the meeting of May $25^{\text {th }}, 1954$, it is clearly revealed, on the one hand, that communist leaders were distrustful of the Catholic bishops and clergy in Romania, while on the other hand, that they were confident to find a solution: "We believe that Pacha's release from prison will enable a solution, with Vatican's consent, to appoint other men due to his release, as well as to the steps we aim to take regarding Márton Áron, thus facilitating the elimination of the problem. The Hungarians also managed to solve the problem without recognizing some prerogatives and without external interference in internal matters." Affirmation by Emil Bodnăraş [my translation])

The initial fear of the Political Bureau members concerning the Catholic clergy's "espionage actions" now transferred to the sects, which - in Gheorghiu-Dej's opinion - had multiplied too much in that period. He wanted the involvement and the support of the historical cults in order to stop the proliferation of the sects. Gheorghiu-Dej even declared that Catholic bishops had to submit reports to the Vatican about their dioceses; it may thus be noticed that he considered this a normal and common practice. Overall, discussions prove that, despite their desire to control the existence and functioning of the Roman Catholic Church in Romania, the members of the Political Bureau wanted an elegant sand satisfactory solution for both parties of this, in their opinion, troubling political and religious matter.

\footnotetext{
${ }^{4}$ Arhivele Naționale Istorice Centrale (ANIC - The Central National Historical Archives in Bucharest), Section "Ministry of Cults, Department for Studies", File 2/1939, sheet 2 (the file contains the translation from Latin into Romanian of the Pope's appointment of Dr. Márton Áron for the Episcopal see in Alba Iulia and some data about his activity, including information about his arrest).

${ }^{5}$ Adrian Nicolae Petcu, Aspecte ale Represiunii... [Aspects of the Repression...], 232.

${ }^{6}$ Ibid. 236.

${ }^{7}$ Marius Bucur, Lavinia Stan, Persecuţia Bisericii Catolice în România. Documente din Arhiva Europei Libere 1948-1960 [The Persecution of the Catholic Church in Romania. Documents from the Free Europe Archives 1948-1960], (Târgu Lăpuş: Galaxia Gutenberg Publishing House, 2005), 37.

${ }^{8}$ Adrian Nicolae Petcu, Aspecte ale Represiunii... [Aspects of the Repression...], 232.

${ }^{9}$ Ibid. 232.
} 


\section{Călin \\ Bishop Augustin Pacha (1870-1954)The Years of Imprisonment and His \\ Release Shortly before His Death}

As regards Bishop Pacha, Bodnăraş said at the end of the discussion: "For Pacha, we are writing the pardon decree today," to which Gheorghiu-Dej added: "It will have favourable consequences for the faithful and the Catholic clergy." ${ }^{10}$ [my translation]

\section{The liberation and the return of Bishop Pacha to Timişoara. The old and sick man and his new work}

At the end of May 1954, one of Bishop Pacha's nephews, stomatologist Gustav Sattler, was summoned to Bucharest where he was told that he would have to visit his uncle together with an official from the Ministry of Internal Affairs, in the custody of this Ministry; the purpose of the visit was to persuade Bishop Pacha to sign a formal pardon request. It seems Pacha had been brought to Bucharest and kept in the custody of the Ministry of Internal Affairs. Dr. Sattler said afterwards that upon his arrival in the capital, he was taken to a room within the Ministry building and left there to wait for the prisoner. It was three o'clock on a Monday afternoon, May $31^{\text {st }}, 1954$. At a certain point, he heard the shuffling of someone's feet and the noise made by a hand groping for the door handle. A few moments later, he was face to face with the octogenarian cleric, who immediately asked: "Is it you, Franz?" - thinking he was looking at his nephew-in-marriage, former deputy Franz Kräuter. Then Dr. Sattler realized the bishop was almost blind and he had to introduce himself. Soon afterwards Pacha started asking about his sister Anna, about his relatives, about that year's crop and how the people were doing at home. The bishop thought he had simply been allowed a visit from his relatives. It was then that the Internal Affairs official, who had attended the meeting from the very beginning, broke in the conversation and told the bishop that the government was willing to offer him a pardon and release him from prison, and all he had to do was sign a formal request addressed to the president of the republic. The document would only oblige him to abide by the laws of the country and to request the pardon. Visibly frightened, Pacha answered: "I haven't held a newspaper in a long while. I don't know the country's laws any more, especially those regarding the Church and, because of this, I can't oblige myself to anything." 11 my translation] The official assured him that the laws were the same as when he had been free so he should not hesitate in writing the formal request. The bishop replied: "I am already old, I can't work anymore. Instead, release my clerics!" [my translation] The official told him that now it was all about him, the bishop, after whom the other priests would follow. To this Pacha answered: "I don't know what my superiors will tell me about this."12 my translation] Again the official assured him that everything was all right. Then Pacha inquired whether Stanciu Stoian was still the Minister of Cults. The answer was a negative one, the name of the current minister was Constantinescu-Iaşi. Having thus been updated about the situation, the bishop agreed to submit the request although he clearly mentioned that he was unable to write after the long years of imprisonment. His nephew, Dr. Sattler let his pen-holding hand on the sheet of paper and thus the pardon request was written in just a few lines and signed. Upon exiting the room, the official took the request from Dr. Sattler's hand and gave it to the Minster of Cults, who had been waiting in the hall. ${ }^{13}$ That same evening, on May $31^{\text {st }}, 1954$, the Official Bulletin was published, containing a decree with only one article, issued by the Board of the Grand National Assembly of the Popular Republic of Romania, which made public the pardon offered to Bishop Augustin Pacha. ${ }^{14}$

\footnotetext{
${ }^{10}$ Adrian Nicolae Petcu, ed., Partidul, Securitatea şi Cultele 1945-1989 [The Party, the Securitate and the Cults 1945-1989], (Bucharest: Nemira Publishing House, 2005), 231-236. (On p. 231, see note 8: AMR, Section Microfilms, roll AS1-409, c. 593-599).

${ }^{11}$ Dr. theol. Franz Kräuter, Erinnerungen an Bischof Pacha. Ein Stück Banater Heimatgeschichte, (Bucharest: ADZ Verlag, 1995), 188

12 Ibid. 188-189.

${ }^{13}$ Ibid., 187-188.

${ }^{14}$ Archivum Dioecesanum Timisoarense (ADT - Archives of the Diocese of Timișoara), Fond Episcop Augustin Pacha [Fond Ep. A.P. - Section Bishop Augustin Pacha.], Folder „Rundschreiben 1950/ Requirierung 1951/ Gerichtsurteil 1951/ Begnadigung 1954”, excerpt from the Official Bulletin, not numbered. To be more specific, it was an excerpt from the Official Bulletin of the PRR no.26/31 May 1954, which includes Decree no. 209 for the pardon of Bishop Augustin Pacha, issued in Bucharest on May 31 ${ }^{\text {st }}$, 1954; the document was signed by the President of the Board of the Grand National Assembly, Dr. Petru Groza and the secretary of the Board of the
} 


\section{Călin 106 \\ Bishop Augustin Pacha (1870-1954)The Years of Imprisonment and His Release Shortly before His Death}

As concerns the release of Bishop Pacha from the communist prison, there were, as already mentioned, many suppositions. There were opinions worth taking into consideration, according to which the somewhat relaxed atmosphere following Stalin's death made this government act possible. ${ }^{15}$ This assumption is of course correct, yet the main motivation for the act was different: it was not a humane act, related to charity, but done to capture the good will of the Catholic population and clergy, and especially to find a quick and state-favourable solution in the "Catholic matter". The possible involvement of Petru Groza in this odyssey may be considered. Having known Pacha for many years, it is possible for Petru Groza to have influenced some of the Political Bureau members in this respect; Groza's family, more specifically the Timişoara living daughter of the "last bourgeois", benefited from medical care in the well-equipped facilities of the Benedictine nuns of St. Lioba ${ }^{16}$ (the St. Anna maternity ward) in the Elizabethan district of Timişoara III. Nevertheless, what Franz Kräuter, doctor in civil law, former deputy and Pacha's nephew, and Friedrich Müller, Evangelical Lutheran Bishop of Sibiu, declared in favour of this hypothesis may be taken into consideration only as credible suppositions, verified solely by their personal and family experiences or by hear-say, as they did not bring any arguments to support their affirmations. ${ }^{17}$

It is certain that Bishop Pacha was released on May $31^{\text {st }}, 1954$. The authorities tried to prepare the prisoner, especially because his physical condition was lamentable. For six weeks he was lodged at the Roman Catholic Archdiocese palace in Bucharest, where he was consulted by doctors and from where he was taken to several university hospitals within the capital for medical investigations. It was here that various visitors from not only Bucharest, but also from Timişoara came to see him. The first to come was the general vicar, Dr. Ferdinand Cziza, who talked to the bishop about the state of the diocese, the budget, the parishes and the faithful. The only free canon was Iván Frigyér, who also held the position of ordinarius substitutes ${ }^{18}$ and who had already sent the bishop a telegram to congratulate him on his return home. He also sent the bishop a letter for the same event on June $11^{\text {th }}$, where he wrote about having searched, together with Dr. Sattler, for a house for the now free man. The Episcopal palace "was full to the roof" by tenants who were housed there after the bishop's arrest. Another canonical house had already been rented, so Dr. Sattler was going to ask the state attorney if the bishop could live in the parish house in the Iosefin district. That house had two rooms that could be tidied up for the bishop. Moreover, the canon mentioned the joy of the faithful in the parishes where he had been to anoint people with Chrism when they heard about the bishop's return home. ${ }^{19}$

On July $1^{\text {st }}$ in Bucharest, the bishop wrote a short circular by which he announced his arrival home. The text was neutral, the stress exclusively on the spiritual side, particularly focusing on his gratitude to God for having watched over him all those years, and there was no reference to the regime in power $^{20}$ all these must have displeased someone... That is why, a new circular - whose contents were

Grand National Assembly, Avram Bunaciu. See also William Totok, Episcopul, Hitler şi Securitatea. Procesul stalinist impotriva ,spionilor Vaticanului” din România [The Bishop, Hitler and the Securitate. The Stalinist Trial against "Vatican Spies” in Romania], (Iaşi: Polirom Publishing House, 2008), 83.

${ }^{15}$ Dr. theol. Franz Kräuter, idem, 187.

${ }^{16}$ Petru Groza's daughter, who lived in Timişoara, gave birth to two children in the above-mentioned maternity ward. Sr. Hildegardis Wulff OSB writes in her memoirs that Petru Groza adopted at the time an unusually amiable attitude towards nuns, something that did not however prevent him from bitterly disappointing them later on. Nonetheless, Sr. Hildegardis defends Petru Groza, explaining that he did not help the Church because he himself did not have a very stable political position. For this, see: Nikolaus Engelmann, Franziska Graf, Peter Krier, Eduard Schneider, Die Liobaschwester Dr. Hildegardis Wulff. Weg, Werk und Vermächtnis, Herausgegeben von der Landsmannschaft der Banater Schwaben, Landesverband Bayern, (Wangen: Walchner Druck GmbH, 1996), 107, 129, 140.

17 Franz Kräuter (Doctor in civil law), Erinnerungen aus meiner christlich-demokratischen Dienstzeit, Manuskriptdruck, (Freiburg: Rota-Druck, 1967) 22, Bischof Friedrich Müller, Erinnerungen. Zum Weg der siebenbürgisch-sächsischen Kirche 1944-1964. Bearbeitet von Hanelore Baier, (Bukarest: Kriterion Verlag, 1995), 105.

${ }^{18}$ Dr. theol. Franz Kräuter, idem, 188-189.

19 ADT, Fond Ep. A.P., Folder „Korrespondenz (amtlich wie privat) nach der Entlassung aus dem Gefängnis“, Letter of ordinarius Frigyér to Bishop Pacha on June 11th, 1954, not numbered.

${ }^{20}$ ADT, Fond Ep. A.P., Folder „Korrespondenz (amtlich wie privat) nach der Entlassung aus dem Gefängnis“, Bishop Pacha's circular written on the occasion of his return to his diocese, versions dated July $1^{\mathrm{st}}$, not numbered. 
similar to the first, but which alluded to the "good will" of the government and which urged the faithful to be "good citizens of our homeland, the Popular Republic of Romania", where everybody must contribute through their diligent work to world peace and contentment - could be made public only on July $15^{\text {th }}, 1954$ in Timişoara and then sent to all parishes to be read from the pulpit. ${ }^{21}$

Meanwhile, the bishop was still in the capital, where he wrote a letter, dated July $7^{\text {th }} 1954$, to the Minister of Cults, in which he requested to move back to his home in Timişoara; furthermore, "as, according to the rules of the Roman Catholic Church, I hold my canonical jurisdiction"22 [my translation], Pacha clearly mentioned the fact that he was aware of the current legal status of the parishes over which he held jurisdiction and that he agreed to their inclusion in the Roman Catholic Diocese of Alba Iulia. He also requested his right to exercise his strictly spiritual duties as a bishop, and he obliged himself to observe the laws in force. He ended the letter by thanking the Board of the Grand National Assembly and the "Distinguished Government for the good will it has showed me" [my translation], assuring the authorities of his own loyalty, of the clergy and of the faithful, to the homeland "Popular Republic of Romania.",23

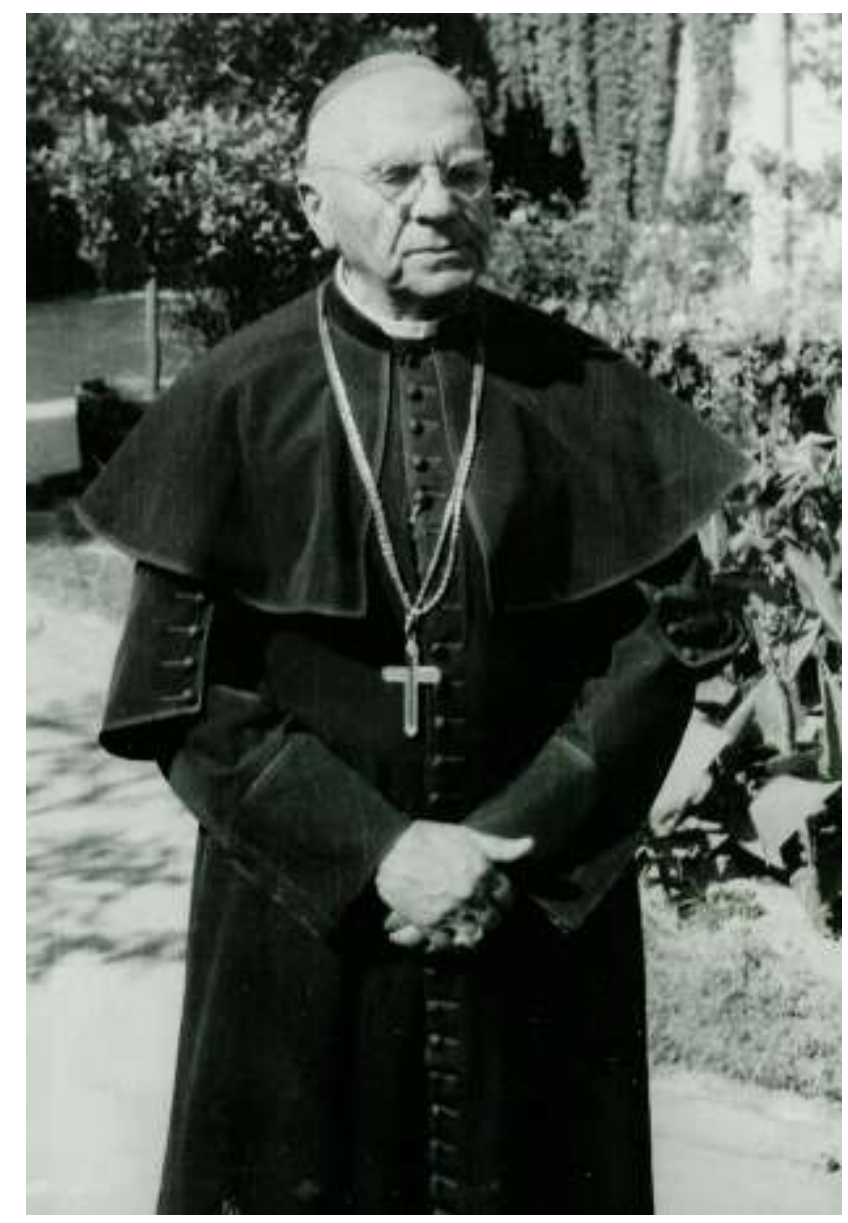

Fig. 1. Bishop Pacha after his release.

Picture taken in the garden of the Iosefin Parrish, Timișoara

Also on July $7^{\text {th }}$, Bishop Pacha was informed by his appointed general vicar, Ferdinand Cziza, who was then in Alba Iulia, that with the help of the Minister of Cults the issue of the house had been

\footnotetext{
${ }^{21}$ ADT, Fond Ep. A.P., Folder „Korrespondenz (amtlich wie privat) nach der Entlassung aus dem Gefängnis“, Bishop Pacha's circular written on the occasion of his return to his diocese, versions dated July $15^{\text {th }}$, not numbered.

${ }^{22}$ ADT, Fond Ep. A.P., Folder „Korrespondenz (amtlich wie privat) nach der Entlassung aus dem Gefängnis“, Bishop Pacha's letter of July 7th, 1954, to the Minister of Cults, not numbered.

${ }^{23}$ Ibid., Bishop Pacha's letter of July 7th, 1954, to the Minister of Cults, not numbered.
} 


\section{Călin 108 \\ Bishop Augustin Pacha (1870-1954)The Years of Imprisonment and His \\ Release Shortly before His Death}

arranged, and that he had been allowed to live in the parish house of Timişoara IV Iosefin district. Cziza also mentioned that the matter of scheduling the sacrament of the Chrism in the parishes and the person to perform it, details already settled by Frigyér, were again part of the bishop's responsibilities. The substitute ordinary was no longer necessary, according to papal norms as soon as the bishop was no longer prevented from exercising his prerogatives. ${ }^{24}$

Although the diocese was recognized by the state only as an archpriestship, and the bishop was retired, from an administrative point of view, his diocesan territory depending, according to state decisions, on the diocese of Alba Iulia, on July $11^{\text {th }}$, 1954, Augustin Pacha appointed a general vicar, namely Ferdinand Cziza, who on the very same day took the pledge of faith, as were the canon laws. At the same time, Pacha chose a secretary, namely Franz Kräuter, a fact that seems to have been accepted by the authorities because they were aware of the bishop's poor health and weak eyesight. Although the appointment (actually the confirmation of Cziza for this post since he was already occupying the position) and his pledge as a general vicar both took place, according to the time's documents, in Timişoara on July $11^{\text {th }}, 1954^{25}$, the same secretary Franz Kräuter specifies in his work dedicated to Bishop Pacha that he arrived in the city only on July $12^{\text {th }}$, and that the appointments were made on July $17^{\text {th }}$. Kräuter also writes that everything occurred in the presence of several witnesses: Georg Wetzl, honorary canon and curate of Timişoara IV Iosefin district, archdean Dr. Adalbert Blaskowitsch, as well as curates Eduard Kandler, Joseph Schäffer and Stefan Balog, who had all come to see the bishop. In a short speech given in Latin, the bishop made a brief presentation of the difficult situation of the diocese, of the priests in prison and of their parishes left with no curates, only to conclude by addressing the general vicar and saying "Confido tibi totaliter!" (I trust you completely). ${ }^{26}$

Even if some of his responsibilities were no longer recognized by the state, the bishop retained the right to give special licenses, to make replacements among the clergy, etc. The general vicar was going to get the state to agree with any step the bishop would take, as long as this was necessary. This reconsideration of the situation eliminated any unclear issues related to canonical jurisdiction, which had appeared during the period when Cziza also worked as a teacher at the Alba Iulia Seminary.

\section{Secret nominations in the canonical succession. Visits, visitors and an active implication in dangerous ecclesiastical and political problems}

Another step, this time a secret one, was to appoint a new "Ordinarius Substitutus" for the diocese, should the bishop have been prevented to exercise his power. ${ }^{27}$ According to a document signed by Pope Pius XII on July $29^{\text {th }}$, 1948, entitled "Nominatio substitutorum," each resident bishop had to appoint two priests, who would, in turn, succeed him as managers of the diocese affairs, and who would exercise executive power just like the diocesan bishop. It was a way to ensure the management of Catholic dioceses in Romania in case of a time when it were impossible to maintain contact with the Holy See. When contact with Rome had been remade, the provisions of the document were no longer valid. All the bishops in the country were informed about this document during $1948^{28}$ by the regent of the Apostolic Nunciature, Gerald Patrik O'Hara. Therefore, Bishop Pacha appointed priest Konrad Kernweiss as the first of the ordinaries in July 1954. The next one, i.e. the one who would succeed Kernweiss, was Ferdinand Hauptmann. As proven by administrative documents, Kernweiss occupied the position between 1954 and 1981, whereas Hauptmann between 1981 and 1983. The fifth ordinary (after Joseph Plesz 1950-1951 and Iván Frigyér 1951-1954) was Sebastian Kräuter, who took over in

\footnotetext{
${ }^{24}$ ADT, Fond Ep. A.P., Folder „Korrespondenz (amtlich wie privat) nach der Entlassung aus dem Gefängnis“, Letter of general vicar Cziza to Bishop Pacha on July 7th, 1954, not numbered.

${ }^{25}$ ADT, Fond Ep. A.P., Folder „Korrespondenz (amtlich wie privat) nach der Entlassung aus dem Gefängnis“, The appointment of priest Ferdinand Cziza as general vicar and the pledge, both dated July 11, 1954, not numbered.

${ }^{26}$ Dr. theol. Franz Kräuter, idem, 191.

${ }^{27}$ Ibid., 191-192.

${ }^{28}$ ADT, Fond: Nunţiatura Apostolică (Section: Apostolic Nunciature), Folder: „Facultates extraordinariae 19481949”, „Nominatio Substitutorum”, not numbered. The document is machine typed in Latin and has 17 sheets of paper, the last one bearing the signature of the Nunciature regent, Archbishop of Savannah, Gerald Patrik O’Hara.
} 
1981, was granted the title "ad nutum Sanctae Sedis," which meant that his occupying the position was sanctioned by the Pope..$^{29}$ He was appointed Bishop of Timişoara by Pope John Paul II on March $14^{\text {th }}$, 1990, and anointed on April $28^{\text {th }}$, 1990, by Archbishop Angelo Sodano, State Secretary and special envoy of the Holy See in this respect. Kräuter was the second cleric to have ever borne this title. ${ }^{30}$

At a certain time, Konrad Kernweiss was thought to have been imposed by the state and the Pope to have had no say in the matter. This is wrong, as Bishop Pacha was the one who, relying on the special provisions of "Nominatio substitutorum," appointed his own successors, who only observed until 1983 what their superior had decided. ${ }^{31}$

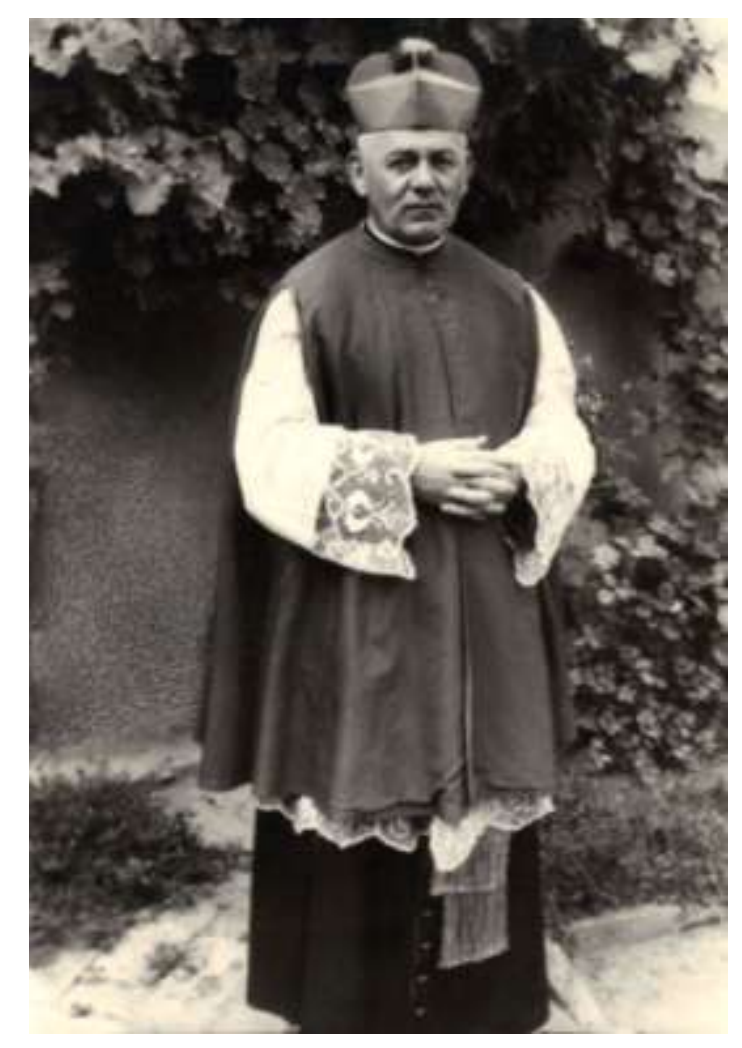

Fig. 2. Monsignore Konrad Kernweiss, ordinarius substitutus of the Diocese of Timişoara

As a man of order and discipline, even though in poor health, the bishop set his daily routine immediately after his release from prison: at 7 o'clock in the morning he would receive Communion, brought by his secretary, priest Franz Kräuter, after which he would pray in private. He could recite or sing many of the morning prayers by heart. Then a light breakfast followed. Before 9 o'clock, he would rise, do some exercise (a habit he had kept from a young age), wash, get dressed and go out into the yard of the parish house for a stroll with his sister. Although she had a strongly affected memory, the bishop would talk to her a great deal. Afterwards, he would have the secretary read the received correspondence, and the bishop would dictate the answers. At 10 o'clock he would have a snack, after which he would receive visitors. When there were no more visitors, he had someone read to him from "The Lives of Saints," the edition edited by Dr. Anton Schütz. The people in charge of this moment were Konrad Kernweiss, at the time also the secret confessor of Notre Dame nuns, and Péter Pázmány, the Iosefin district chaplain. At one o'clock in the afternoon he would have lunch and a rest. For most of the afternoon the bishop would remain by himself. From five to seven o'clock in the evening a

\footnotetext{
$29 * * *$ Schematismus Dioeceseos Timisoarensis pro Anno Domini 2005-2006, (Timişoara: Typis Typographiae "Mirton", 2005), 10.

${ }^{30}$ ADT, Fond Episcop Sebastian Kräuter (Section Bishop Sebastian Kräuter), Folder containing the papal certificate of appointment as bishop, dated March 14th, 1990, not numbered.

${ }^{31}$ Dr. theol. Franz Kräuter, idem, 192.
} 
priest from around the city would come to keep him company. They would often laugh at the collection of stories the bishop himself had written in the mid-1940s. He would have dinner at 7 o'clock in the evening, after which his relatives from Timişoara would visit him: Heinrich Metzenrath with his wife and daughter, Dr. Gustav Sattler and his wife, Hedwig Schmidt and her family. At 9 o'clock in the evening he would retire for bed. He patiently bore his poor eyesight neighboring on blindness. He never complained. He summoned an eye specialist in the city, Dr. Popovici, who prescribed him a treatment. There were modest improvements. He would always pray, using the prayer of another old bishop: "Dear God, leave me my eyes, for he is poor who cannot see. But Lord, if you take my eyesight, leave me the light of reason, for he is poorer still who has lost clarity of thought. But if you, Lord, take this as well, then please leave me the light of faith so that I may see You surrounded by Your everlasting light. ${ }^{, 32}$ [my translation] Bishop Pacha briefly mentions his poor eyesight in a letter written in Latin on July $20^{\text {th }}, 1954$, to prelate Mons. Traian Jovanelli, ${ }^{33}$ vicar of Bucharest. Pacha was also thanking him for having been a guest at the Episcopal palace in Bucharest, where Jovanelli himself had been the host. ${ }^{34}$

After moving to the parish house in the Iosefin district of Timişoara, other formal visits - albeit very amiable - followed. The Metropolitan Bishop of Banat, Dr. Vasile Lăzărescu visited Bishop Pacha, openly showing his joy for the latter's return home. A few days later, when his health allowed it, Pacha returned Lăzărescu's courteous visit. Simple people, such as the women employees of a red pepper powder laboratory, located in the basement of the parish house, paid the bishop an ad hoc visit one afternoon, bringing him a big bouquet of roses to show their happiness for their spiritual shepherd's return from prison.

The fact that at an old age, during hard times and after a four-year absence because of imprisonment, Bishop Pacha came back to the leadership of the diocese in actual fact and not just as an honorary member, is reflected in the letters he sent his priests. He wrote not only official but also spiritual correspondence with several priests, of whom we mention here priests Lajos Párvy of Gărâna, Josef Pettla of Totina, Julius Wünsche of Recaş and his chaplain, Eugen Gebhard. Each of them wanted something solved: Párvy the Chrism sacrament in his parish, Pettla a solution to the issue of "imposed domicile" for Totina, while Wünsche was celebrating his gold jubilee since having been consecrated as a priest. ${ }^{35}$ Still with regard to administrative matters, he had a long correspondence with the parish of Maria Radna, managed by Franciscan monks, where the jurisdiction of the parish administrator was unclear, while the convent's spiritual guardian, Pater Odorik Szentmártoni OFM requested this in writing (on August $9^{\text {th }}, 1954$ ). In this respect the bishop even appointed two consultants; considering it was a parish with a convent, i.e. including regular clergy, the two consultants were a regular cleric and a secular one: P. Paulus Weinschrott SDS and priest Dr. Josef Schwartz, professor of theology. ${ }^{36}$ It has to be mentioned that, even if they were officially disbanded, the orders were still recognized on a diocese level. Still in relation to the bishop's activity about the management of the parishes, we exemplify the special licenses for mixed marriages at Făget and Gătaia (July-September 1954). ${ }^{37}$

True to the spirit of Canon 1579 of the Roman Catholic Church Code of Canon Law, Bishop Augustin Pacha appointed a new ecclesiastical court for the Timişoara Diocese on September $18^{\text {th }}$, 1954. The members of this court had to be at the bishop's house on September $23^{\text {rd }}, 1954$, where they would take the pledge. The court was composed of: Iván Frigér - officialis, Adalbert Blaskowits vice-official, Dr. Josef Schwartz - notary public, Peter Pázmány - "advocatum pauperum,” Franz

\footnotetext{
${ }^{32}$ Ibid., 192-193.

${ }^{33}$ Acta Apostolicae Sedis [AAS], Commentarium Officiale, Annus XXVI - Series II - Vol. I, Romae, Typis Polyglottis Vaticanis, MDCCCCXXXIV [1934], 575. Stanislau Traian Jovanelli was nominated on the first of March 1934 supernumerary secret papal chamberlain, and inhabitet the title of Monsigniore.

${ }^{34}$ ADT, Fond Ep. A.P., Folder „Korrespondenz (amtlich wie privat) nach der Entlassung aus dem Gefängnis“, Bishop Pacha's letter to vicar Jovanelli, dated July 20th, 1954, not numbered.

${ }^{35}$ ADT, Fond Ep. A.P., Folder „Korrespondenz (amtlich wie privat) nach der Entlassung aus dem Gefängnis“, letters to various priests, not numbered.

${ }^{36}$ ADT, Fond Ep. A.P., Folder „Korrespondenz (amtlich wie privat) nach der Entlassung aus dem Gefängnis“, correspondence with the spiritual guardian of Maria Radna, not numbered.

${ }^{37}$ ADT, Fond Ep. A.P., Folder „Korrespondenz (amtlich wie privat) nach der Entlassung aus dem Gefängnis“, Episcopal licenses 1954, not numbered.
} 
Kräuter - promoter of justice and "defensor vinculi". Pro-synodal judges were appointed: Iván Frigér, Georg Wetzl, Adalbert Blaskowits, P. Johannes Blum SDS, P. Stefan Christ SDS, P. Carolus Haubenreich SDS, Konrad Kernweiss and Stephan Schultz. ${ }^{38}$

Two letters written in Latin and addressed to the Holy See are particularly interesting and bear the signature of Bishop Pacha. It is unknown whether these letters were actually sent, or whether they reached their destination, and if they did, how the delivery was made; one letter is dated October $1^{\text {st }}$, 1954, while the other October $10^{\text {th }}$. The then ordinary of the diocese of Alba Iulia, Adalbert Kovács, who was also a curate of Covasna, had trouble in exercising his authority. The same was true for the ordinary of Satu Mare, Károly Pákocs. Pacha wrote in his letter that several priests from the abovementioned dioceses did not obey these two superiors, claiming they had neither the acceptance of the state nor of the appropriate cathedral chapters in order to exercise this function. Because of this, upon the request of the two ordinaries and as a solution to eradicate spiritual anarchy, the bishop from Banat asked the Holy See to confirm the two as leaders of their respective dioceses or to designate him, as a bishop and older member of the same metropolitan province, to clarify the matter.

Furthermore, the bishop requested explanations about jurisdiction and succession between a general vicar and a substitute ordinary, or between the two substitute ordinaries appointed by the bishop. He mentioned the fact that his general vicar, Dr. Ferdinand Cziza, was in Alba Iulia, where he also worked as a teacher of theology, answering to the ordinary there in terms of matters and problems pertaining to the disbanded diocese of Timişoara.

It is of particular interest the manner in which he wanted to receive the answer: not only by post, but also by means of the shows broadcasted in Latin, Romanian, German or Hungarian on Vatican Radio. $^{39}$

Another delicate pastoral matter touched on by Pacha as early as July $22^{\text {nd }}, 1954$, was his pastorate and the financial situation of the faithful and of the Roman Catholic priests deported by the communist authorities to Bărăgan. In a letter addressed to his general vicar, bearing the above-mentioned date, he asks the general vicar to investigate the matter. Of the priests, László Túry and Zoltán Buding had been deported, both of them rather young at the time. We do not know vicar Cziza's reply, but it is certain that on September $21^{\text {st }}$, the general vicar of Bucharest, canon Stanislau Traian Jovanelli, sent the bishop of Timişoara a short report, dated September $4^{\text {th }}$, a document in which the curate of Brăila, Falewski, summed up the holy High Mass services, the weddings, the christenings, the funerals and the first Communions that took place at Zagna, Măzăreni, Vădeni-Zagna and Urleasca. The phrase that "all Masses happen out in the open" clearly shows the living standards of those villages. ${ }^{40}$

Pacha's courageous attitude is referred to in a project requesting the return of the diocesan library books, confiscated in October 1951. The books were then in the city library of Timişoara, which did not want to give them back unless a new decision was made in this respect by the Ministry of Cults. We have not managed to find out whether the request was submitted, but it is certain that the books were never returned ${ }^{41}$.

To return now to Pacha's pastoral activity, it is known that, although almost blind and extremely weak, the bishop used to take part to Sunday Mass in the parish church of Iosefin district, which was very close to his home. On his way out, along the central aisle of the church, he would bless the faithful. There were many who burst into tears, deeply touched by the bishop's gesture and by the physical condition of their spiritual father. On the last Sunday of every month, the bishop would take part in a solemn mass at the Dome of St. George (the Roman-Catholic cathedral of Timişoara), also because in 1954 they celebrated one hundred years since the proclamation of the dogma of the Immaculate Conception of the Virgin Mary. On the last Sunday of September, Pacha attended his last Mass at the Dome. When he was drawing closer to the cathedral, the big Episcopal bell was told in his

\footnotetext{
${ }^{38}$ ADT, Fond Ep. A.P., Folder „Korrespondenz (amtlich wie privat) nach der Entlassung aus dem Gefängnis“, document for the appointment of the members of the ecclesiastical court on September 18th, 1954, not numbered.

${ }^{39}$ ADT, Fond Ep. A.P., Folder „Korrespondenz (amtlich wie privat) nach der Entlassung aus dem Gefängnis“, two letters to the Holy See (October 1st and 10th, 1954), not numbered.

${ }^{40}$ ADT, Fond Ep. A.P., Folder „Korrespondenz (amtlich wie privat) nach der Entlassung aus dem Gefängnis“, correspondence on the issue of the people deported to Bărăgan, not numbered.

${ }^{41}$ ADT, Fond Ep. A.P., Folder „Korrespondenz (amtlich wie privat) nach der Entlassung aus dem Gefängnis“, request for the return of the Episcopal library books, September 18th, 1954, not numbered.
} 


$$
\begin{array}{r|r}
\text { C. Călin } & 112 \\
\text { Bishop Augustin Pacha (1870-1954)The Years of Imprisonment and His } & \\
\text { Release Shortly before His Death } &
\end{array}
$$

honour; he himself had given the bell to the religious building when he was ordained a bishop. Deeply touched - say the eye-witnesses - he may not even have thought to hear these bells for the last time. ${ }^{42}$

\section{The last days and the death of Bishop Pacha. The Funeral and the succession}

Even if after having been released from prison, the bishop's health improved as much as possible given his old age (he even gained 10 kilograms in weight), fatigue appeared more and more often. $\mathrm{He}$ never complained, although he sometimes made comments about the paleness of his hands or about his general condition. On October $24^{\text {th }}$ he experienced severe pain, which Pacha also had during his imprisonment. His doctor, Emmerich Bauer, was fetched and he gave the bishop a sedative. It was not very well known if it was intestinal cancer or a condition of the prostate. Following the discussion with family members, surgeon Ion Danicico, the manager of "Clinicile Noi" Hospital, was also consulted. The doctors prescribed him powder sedatives, which could be administered even if there was no doctor around. On the last day of October, the pains returned no less than four times. On November $1^{\text {st }}$ the pains were so severe that Dr. Bauer gave the patient a considerable dose of morphine. The next day the patient experienced intermittent moments of unconsciousness. This is when the bishop's confessor, P. Stefan Christ SDS, was called in order to give him the sacraments for the dying. As the bishop's state worsened and hospital care was imminent, secretary Franz Kräuter conferred the Final Anointing on him, granting him general absolution and the papal blessing with plenary indulgence. At lunchtime, on November $2^{\text {nd }}$, Bishop Pacha was taken to hospital in an ambulance. Medical investigations performed at the hospital did not bring any necessary clarifications to establish a diagnosis. On November $3^{\text {rd }}$, the doctors decided to proceed with the surgery. Surgeon Ion Danicico believed that waiting for too long could only contribute to further weakening the patient. That very same day surgeons Ion Danicico and Pius Brînzeu removed a prostate tumour from the bishop's body and also did a hernia operation on him. Pacha survived surgery but recovery was all about his old age. Despite all this, the patient never woke back from anesthesia. Pneumonia, however, complicated the entire situation. On the morning of November $4^{\text {th }}$ the bishop was brought back home, to the parish house of Iosefin district. As his vital signs were getting weaker, at half past six in the evening, a candle was lit for the dying man and appropriate prayers were begun. In a matter of hours, the octogenarian cleric passed away. While the priest who was praying out loud first said "Lord, may he rest in peace!", none of the people present could reply because of tears. Augustin Pacha was immediately dressed in pontifical vestments and funeral arrangements began.

\footnotetext{
${ }^{42}$ Dr. theol. Franz Kräuter, idem, 194.
} 


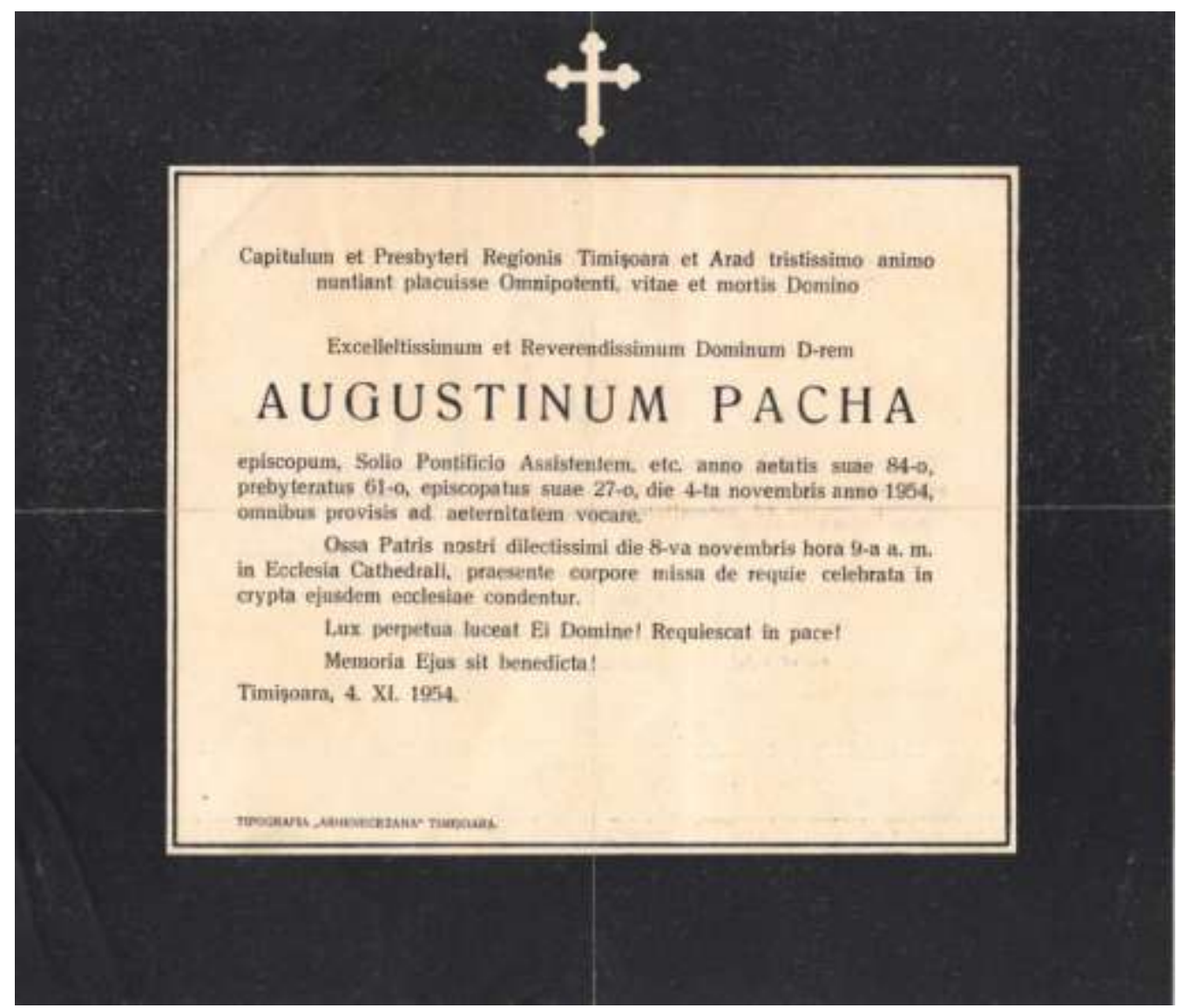

Fig. 3. The Obituary of Bishop Pacha in Latin

As his death occurred on a Thursday, November $4^{\text {th }}$, at half past six in the evening, and the priests could not be absent from their parishes on Saturday and Sunday, the date for the funeral was set at nine o'clock in the morning on Monday, November $8^{\text {th }}, 1954$, of which the other dioceses in the country and the civil authorities were informed. On Friday evening, November $5^{\text {th }}$, in the presence of relatives, priests and the nuns who had looked after him, a first ceremony was performed in the deceased's room of the Iosefin district Parrish house. The local curate, honorary canon Georg Wetzl and both his chaplains recited the prayers. ${ }^{43}$ Immediately afterwards, the body of Bishop Pacha was moved to the Dome St. George, as the funeral place was the crypt of that cathedral, according to his last will and testament. ${ }^{44}$ Although Stefan Fiedler, Bishop Emeritus of Satu Mare and Oradea, former colleague and former general vicar of Pacha's, announced his arrival to perform the funeral service, his health prevented him. ${ }^{45}$ Instead, he designated the only canon still free, Iván Frigér.

Saturday and Sunday were genuine pilgrimage days to the distinguished bishop's bier for the faithful in the city as well as from nearby villages. On Sunday, the long line of people who passed by the bier to pay their last respect was literally endless. At nine o'clock on Monday morning the funeral began with a Requiem. Even though it was a working day, the crowd inside the Dome and in the Union Square was immense. Those who had not managed to enter the cathedral had to stay outside to at least be a part of the funeral procession. Among the ones present were Adalbert Kovács, ordinary of Alba Iulia, canon Adalbert Schriffert from Oradea together with his secretary Ferenc Bélteky, Msgr. Károly Pákocs from Satu Mare, and Vasile Begu on behalf of the Archdiocese in Bucharest. Representing the Metropolitan see of Banat, there were Dr. Nicolae Corneanu (counselor at the time),

\footnotetext{
${ }^{43}$ Ibid., 197-200.

${ }^{44}$ ADT, Fond Ep. A.P., Folder: „Tod-Beisetzung-Beileidsschreiben-Testament 1948/1954”, Augustin Pacha's last will and testament, dated September $27^{\text {th }}, 1949$, not numbered.

${ }^{45}$ ADT, Fond Ep. A.P., Folder: „Tod-Beisetzung-Beileidsschreiben-Testament 1948/1954”, Bishop Fiedler's telegram to announce his attendance at the funerals, dated November 6th, 1954 (Saturday), not numbered.
} 


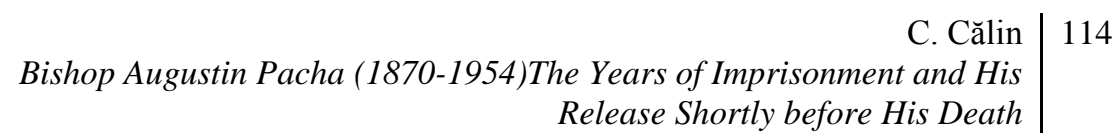

archpriest Vuia and another counselor cleric. The protestant cults were represented by Pastors István Debreczény (Reformed), Leo Peuker (Reformed), and Pál Matos (Evangelical Lutheran). The Serbian Orthodox general vicar, Stefan Tomici, also attended the service, as he was an old acquaintance of Pacha's. The Israeli community was represented by rabies Dr. Maximilian Drexler and Dr. Ernest Neumann. The Ministry of Cults in Bucharest sent as representatives' general director Marin Surică and regional inspector Sever Popescu. The "Popular Counsel" (i.e. the City Hall) of Timişoara also had two representatives at the funeral. ${ }^{46}$

According to the prescribed rites, the priest conducting the funeral was assisted by a deacon, Konrad Kernweiss, by a sub-deacon Ferdinand Hauptmann, and by honorary deacons Dr. Ferdinand Cziza and P. Johannes Bulm SDS. Acolytes were P. Gottfried Borth SDS and brother Pius Hoffmann SDS. Sebastian Kräuter and Wenzel Demele were turiferari. Franz Kräuter presided over the ceremony. Of the diocese clergy 108 priests were present at their bishop's committal.

The praise of the deceased bishop was spoken in Romanian, German and Hungarian by canon Iván Frigér. It was also he who performed by himself the actual burial rite in order to avoid jurisdiction issues. After that, the coffin was carried by priests towards the Dome exit, under the choir balcony. There, the representative of Măureni village, Pacha's birthplace, gave a short farewell speech. A small bag of earth from Măureni was brought for the occasion and it was placed in the Dome crypt together with the simple oak coffin. Bishop Pacha, the most beloved clergyman of the Banat Swabians was placed below the high altar, next to the final resting place of Bishop Nikola Stanislavich $(+1750)$, who had also been cherished by local Bulgarian ethnics. In front of the open niche, the new diocese ordinary, Konrad Kernweiss, introduced himself to the clergymen present as such, similar to Elisha taking over prophet Elijah's mission in the Old Testament. ${ }^{47}$

The marble slab covering the niche now bears the bishop's coat of arms and the inscription: "Dr. Augustin Pacha, primus episcopus Timisoaraensis 1870-1954." as well as the motto: "Beati mortui, qui in Domino moriuntur!"

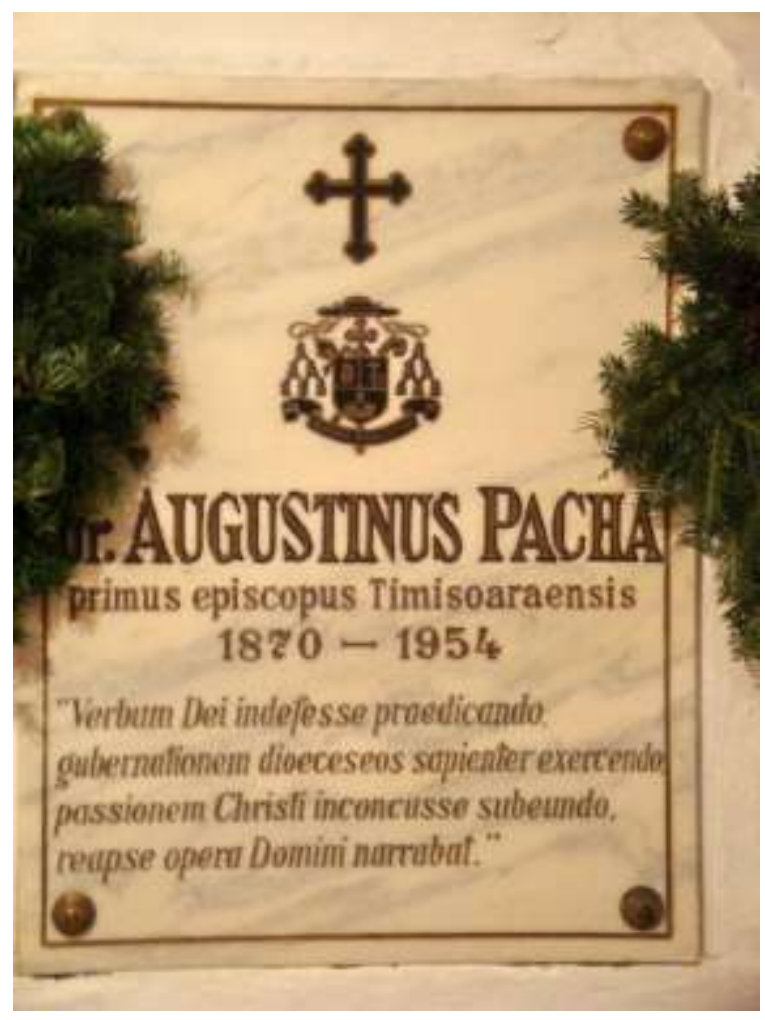

Fig. 4. The inscription of the tomb of Bishop Pacha in the crypt of the Dome St. George in Timișoara

\footnotetext{
46 ADT, Fond Ep. A.P., Folder: „Tod-Beisetzung-Beileidsschreiben-Testament 1948/1954”, the list of representatives of other cults and officials, not numbered; Dr. theol. Franz Kräuter, idem, 204

${ }^{47}$ Dr. theol. Franz Kräuter, idem, 201-205.
} 


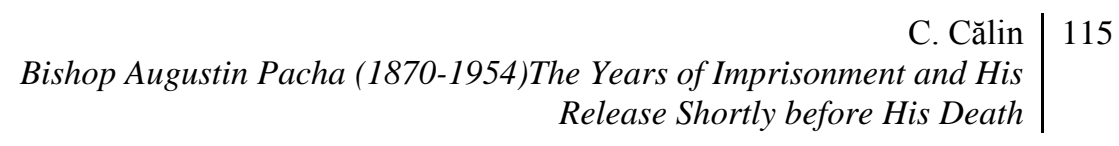

\section{Conclusions}

The trial of the Pacha lot represents one of the grandest juridical frame-ups in the history of Romania. An iniquitous political and ideological instrument used by the Secret Police, the trial was a perfect example of manipulation and diabolic construction of a "case" that was meant to be set an example for those who would dare, from then on, to even flirt with the West. From a different point of view, this trial was meant, on the one hand, to show how corrupt the political class before August $23^{\text {rd }}, 1944$ had been, and on the other hand, to denigrate and disgrace the Catholic Church in the eyes of the populace, and why not, of its own faithful. The Catholic Church was seen by communists as being one of the greatest enemies of the "popular democracy regime" not only through its political influence, but also and especially through its supranational structure and the loyalty of the clergymen and the faithful. Bishop Pacha was one of the victims of this frame-up, as he was reserved, despite his very old age, the leader position of this "lot," which also borrowed his name.

Both as a simple man and as a cleric, Bishop Pacha was several times in the wrong place at the wrong time. He honestly thought that he could change or at least influence the Nazis' attitude, beginning with Adolf Hitler and ending with the youth he had greeted with the Nazi salute at their demonstrations in Timişoara and Aradu Nou. Some studies consider the cleric of Banat as a triple victim: first, a victim of his own illusions for having assumed that Hitler would agree with his appeal and that the Catholic Church of Banat would no longer suffer from the national socialist propaganda; second, a victim of the Nazis in Romania, who saw him as the tool of universal, anti-national and antiracist Catholicism; and third, a victim of the communists who used him and his fame to denigrate the Catholic Church and make an example out of him in terms of the communist fight against supranational Catholicism in Romania, according to Kremlin expectations.

The bishop's personality and his religious, cultural and political choices should never be forgotten. Deeply rooted in the traditions and the German people of Banat, Pacha always tried to provide his conationals with peace and quiet, and a constant Catholic spiritual course, at least from the point of view of denomination and of the influence he held in political environments.

\section{References}

Acta Apostolicae Sedis [AAS], Commentarium Officiale, Annus XXVI - Series II - Vol. I, Romae, Typis Polyglottis Vaticanis, MDCCCCXXXIV [1934].

Bucur, Marius and Lavinia Stan. Persecuţia Bisericii Catolice în România. Documente din Arhiva Europei Libere 1948-1960 [The Persecution of the Catholic Church in Romania. Documents from the Free Europe Archives 1948-1960], Târgu Lăpuş: Galaxia Gutenberg, 2005.

Doboş, Dănuţ. "Arhidieceza de Bucureşti în perioada 1948-1989" [The Archdiocese of Bucharest during 1948-1989], in Biserica Romano-Catolică din România în timpul perioadei comuniste (1948-1989) [The Roman Catholic Church in Romania during the communist period (1948-1989)], edited by the National Commission for the Study of the History of the Roman Catholic Church in Romania. Iaşi: Sapientia Publishing House, 2008.

Engelmann, Nikolaus and Franziska Graf, Peter Krier, Eduard Schneider. Die Liobaschwester Dr. Hildegardis Wulff. Weg, Werk und Vermächtnis, Herausgegeben von der Landsmannschaft der Banater Schwaben, Landesverband Bayern. Wangen: Walchner Druck, 1996.

Kräuter, Franz (Doctor in civil law). Erinnerungen aus meiner christlich-demokratischen Dienstzei. Manuskriptdruck. Freiburg: Rota-Druck, 1967.

Kräuter, Franz (Doctor in Theology). Erinnerungen an Bischof Pacha. Ein Stück Banater Heimatgeschichte. Bucharest: ADZ Verlag, 1995.

Müller, Friedrich (Bischof). Erinnerungen. Zum Weg der siebenbürgisch-sächsischen Kirche 19441964. (Bearbeitet von Hanelore Baier). Bukarest: Kriterion Verlag, 1995.

Partidul, Securitatea şi Cultele 1945-1989 [The Party, the Securitate and the Cults 1945-1989], ed. Adrian Nicolae Petcu. Bucharest: Nemira Publishing House, 2005.

Petcu, Adrian Nicolae, Aspecte ale Represiunii Antireligioase în anii '50. Dosarul 15.563 [Aspects of the Antireligious Repression in the '50es], in Pro Memoria. Revisă de istorie Ecleziastică [Pro. Memoria. Magazine for Ecclesiastical History], București, Nr. 5 / 2006. 


\section{Călin 116 \\ Bishop Augustin Pacha (1870-1954)The Years of Imprisonment and His \\ Release Shortly before His Death}

Procesul unui grup de spioni, trădători şi complotişsti în slujba Vaticanului şi a centrului de spionaj italian, Bucureşti, 10-17 septembrie 1951 [The Trial of a group of spies, traitors and plotters in the service fo the Vatican and the Italian centre for espionage, Bucharest, 10-17 September 1951]. Bucharest: The State Publishing House for Scientific Literature, 1952.

Schematismus Dioeceseos Timisoarensis pro Anno Domini 2005-2006. Timişoara: Typis Typographiae "Mirton", 2005.

Totok, William. Episcopul, Hitler şi Securitatea. Procesul stalinist împotriva „,spionilor Vaticanului" din România [The Bishop, Hitler and the Securitate. The Stalinist Trial against "Vatican Spies" in Romania]. Iaşi: Polirom Publishing House, 2008.

Arhivele Naţionale Istorice Centrale (ANIC - The Central National Historical Archives in Bucharest)

Fond: Ministerul Cultelor. Direcția de Studii (Section "Ministry of Cults, Department for Studies").

Archivum Dioecesanum Timisoarense (ADT - Archives of the Diocese of Timișoara),

Fond: Episcop Augustin Pacha (Ep. A.P. - Section Bishop Augustin Pacha).

Fond: Nunţiatura Apostolică.

Fond: Episcop Sebastian Kräuter (Section Bishop Sebastian Kräuter). 